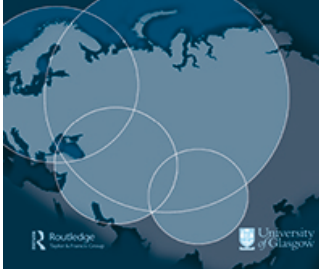

\title{
Cold War Energy. A Transnational History of Soviet Oil and Gas
}

\section{Maurizio G. Totaro}

To cite this article: Maurizio G. Totaro (2018) Cold War Energy. A Transnational History of Soviet Oil and Gas, Europe-Asia Studies, 70:8, 1345-1347, DOI: 10.1080/09668136.2018.1520525

To link to this article: https://doi.org/10.1080/09668136.2018.1520525

册 Published online: 02 Nov 2018.

Submit your article to this journal

Џlll Article views: 138

Q View related articles $₫$

View Crossmark data \lceil 
led to the suspension of cooperation between Russia and the West and decreased the potential for resuscitating relations.

Chapters 3 and 4 explore Russian domestic politics. Chapter 3 deals with the wave of demonstrations in December 2011 and the dynamics of the 2011-2012 elections. Monaghan claims that grasping the scale, mix and balance of the demonstrations is difficult. Western observers mistakenly viewed the protesters as a real opposition movement, whereas they were united only in decrying the elections as fraudulent. Overall, despite the protests, there was no substantial political challenge to Putin in the 2011-2012 elections. On this basis, Monaghan concludes that the nonsystemic opposition does not enjoy the support of the wider population; that the liberal opposition has been completely marginalised; and that the remaining opposition is 'left-leaning' (p. 115). In Chapter 4, entitled 'Beyond Putin? Deciphering Power in Russia', Monaghan develops a model of the governing elite in Russia in which three layers of government - the core leadership, 'federal locomotives' (a group of people from politics, government apparatus and big business who lead strategically important projects and are personally accountable to Vladimir Putin) and managersare analysed to provide an understanding of contemporary Russia. According to this model, the All-Russian Popular Front (ONF) and the Agency of Strategic Initiatives (ASI) are the springboard organisations for the next generation of Russian leaders. The conclusion repeats the call to overcome ethnocentrism and political optimism to formulate a clearer interpretation of Russia in the West.

Overall, Andrew Monaghan presents a convincing analysis of the strategic dissonance between the West and Russia. In this well-written book, which targets policymakers more than the scholarly community, he not only clearly lays out the problem but also points to a solution.

ZERRIN TORUN, Assistant Professor, Department of International Relations, Middle East Technical University, Üniversiteler Mahallesi Dumlupınar Bulvarı No 1, Çankaya, Ankara 06800, Turkey. Email: zerrin@metu.edu.tr

https://doi.org/10.1080/09668136.2018.1520519

ZERRIN TORUN (C) 2018

Jeronim Perović (ed.), Cold War Energy. A Transnational History of Soviet Oil and Gas. Cham: Palgrave Macmillan, 2016, xxix + 425pp., £74.50/€106.99 h/b.

WITHOUT AN ASSESSMENT OF THE ROLE OF OIL AND GAS IN ITS UNRAVELLING, the history of the Cold War would be incomplete; this is the premise on which this comprehensive volume rests. Throughout its pages, the reader finds herself immersed in a dynamic assemblage of state agencies, oil companies, bureaucrats, politicians, international institutions, contracts and technologies, as energy flows reshape political allegiances and economic blocs.

As the editor puts it, early in the preface, the Iron Curtain was nowhere 'more porous than in the domain of energy flows' (p. vi). By striking a blow against simplified notions of an East-West divide, the chapters in this book reveal how, on the one hand, intra-bloc cohesion and inter-bloc rivalry remained strategic concerns on both sides of the Iron Curtain, constraining the actions that could be taken by the members of the respective camps. On the other hand-and arguably more interestingly - it is shown how countries and blocs were internally fractured along lines corresponding to different interest groups and lobbies, whether within the Soviet Union and its Eastern European partners, or NATO allies. What qualified as a matter of security was contested and subject to negotiation and debate between the two superpowers and their respective allies, with priorities and boundaries between energy and military security shifting over time. Ultimately, as 
the chapters collectively show, the logic of strict ideological and economic competition often associated with the Cold War was continuously modulated by national interest and economic pragmatism. Flows of energy, and specifically of oil and gas, were both an object of dispute and cooperation between East and West, as well as a structuring agent in the production of interdependencies whose legacy continues to affect three-way political-energy relations between Russia and Eastern and Western European countries today. At the end of the volume, following the expansion of infrastructural, financial and personal contacts between the two blocs, the reader is left with a very different map of Europe: one marked by increasing cooperation rather than competition, and by evolving interconnection rather than isolation.

The book comprises 12 chapters divided into three parts corresponding to three respective phases of Cold War energy relations. In addition, a comprehensive introduction by the editor offers an overview of the evolving role played by oil in Soviet thinking and policy- and decision-making, whilst the concluding chapter by Margarita M. Balmaceda assesses the current implications and legacies of the locked-in energy interdependency between Russia, the former Soviet republics to its west, and European member states.

The chapters included in the first part analyse the period between the end of WWII and the early 1960s, when the Soviet Union re-entered the global oil market, causing mixed reactions and bitter conflicts within the Western bloc. This is particularly evident in the chapters by Niklas Jensen-Eriksen and Roberto Cantoni. The first, based on British archival materials, reveals how the Soviet 'oil offensive' sparked a conflict between the country's Board of Trade and the Ministry of Power on the issue of oil imports from the USSR. The author argues that the two governmental departments acted in fact as lobby groups, protecting the interests of the local British oil and coal industry, and those of the manufacturing industry, respectively. On a different scale, Cantoni's chapter looks at the concerns that escalating Soviet oil exports and infrastructure-building caused within NATO and the EEC. In particular, the author shows how pipes, and the uncertainty over their 'ontological' status (p. 145), became a matter of contention between, on the one hand, countries such as West Germany, Italy and the UK, eager to continue trading technology for oil with the Soviets, and on the other, the US and France, who backed an embargo finally enforced in 1962. Whilst the US stressed the military nature of the pipeline in order to support a proposed embargo on the sale of pipes to the Soviet Union, the Germans deployed a technical argument in order to argue that their pipes were intended to be used for gas (a non-strategic resource) and not for oil. The British, on the other hand, argued that an embargo would be largely ineffective: since Soviet pipes lacked any usage distinction, this gave the USSR the flexibility to increase internal production in order to circumvent a stop to imports from Europe, where oil and gas pipes could be distinguished by metallurgical properties and pressure capacities. Thus, debates on what a pipe was, argues Cantoni, were shaped by different technological arguments, economic considerations and political interests which constituted a space of struggle to control or suppress trade with the Soviet Union.

Internal and international power struggles are also at the centre of the second part of the book, which focuses on the expansion of East-West relations during the détente. The chapter by Viacheslav Nekrasov analyses the failure of Khrushchev's project to enhance a domestic petrochemical industry, delving into the struggles between rentier groups within the chemical and metallurgical industries. The allegiance between the latter and the 'gas faction' meant that, in the years to come, the Soviet Union continued to be highly dependent on the import of technology, including large-diameter pipes. Italy and its then state-owned oil and gas company ENI were at the forefront of the supply of this technology and, as the chapter by Elisabetta Bini scrupulously documents, this relationship challenged US energy policy as well as the Seven Sisters' dominance of the global oil market, and was used by Italy as a tool to strengthen its own role within NATO. It also anticipated forms of cooperation which would consolidate between Western Europe and the USSR during the détente. 
Energy relations between the USSR and its Eastern European allies are the focus of the book's last section. Falk Flade's chapter looks at the infrastructural lock-in created during the 1970s through the construction of the Druzhba pipeline, and how this consolidated the dependence of the satellite states on Soviet energy supply, whilst committing the USSR to a project that proved unsustainable in the long run. Indeed, as the following chapter by Suvi Kansikas shows, energy was far from being a straightforward lever of influence in the hands of the Soviets. Members of the Council for Mutual Economic Assistance (CMEA) retained considerable agency in determining energy prices; their relative rigidity, coupled with the need for the Soviets to implement reforms without distressing the economies of its Eastern Bloc allies, prevented the USSR from moderating CMEA mechanisms to better suit its own purposes. This intra-bloc interdependency increased considerably from the 1960 s to the 1980s and, as shown by Lorenz Luthi, eventually the Soviet Union found it difficult to continue supplying its allies. As the Soviet Union went through an 'oil crisis' during the 1980s, Moscow decision-makers started to consider intra-bloc energy relations as a burden; the result was a gradual unravelling of bloc economic integration, until its collapse in 1991.

If a criticism of the book can be made, this concerns its geographical focus. Besides a chapter by Nataliia Egorova on the Iranian crisis of 1945-1946, the book is exclusively concerned with power struggles and energy relations in Europe. For a transnational history of Soviet oil and gas to be exhaustive, it might have been useful to broaden it to other continents. For instance, Algeria, Egypt, Iraq and Libya were all supplying oil to the USSR whilst retaining important relationships with their former colonial masters. On a similar note, we learn close to nothing about the role played by the Soviet oil- and gas-producing republics and their decision-makers, party officials and scientists. With the exception of an assessment of the 'Baku lobby' (the chapter by Felix Rehschuh) in resisting the development of the Ural-Volga region after WWII, developments in the Turkmen and Kazakh SSRs are left unexplored. And yet, starting from the 1970s, collaborative engagement with Western industrial enterprises was explored in both regions. Moreover, they had to compete for economic resources and technology with other oil regions of the USSR, especially with Western Siberia.

Overall, the book is a welcome, rigorous, and much needed in-depth exploration of energy politics during the Cold War in Europe. Its geographical shortcomings are an invitation to continue and expand the study of the energy/Cold War nexus and its history and legacies, across and beyond its European core.

Maurizio G. Totaro, Marie Skłodowska-Curie PhD Fellow, Department of Conflict and Development Studies, Faculty of Political and Social Sciences, University of Ghent, Universiteitstraat 8,9000 Ghent, Belgium.Email: mauriziogiuseppe.totaro@ugent.be

http://dx.doi.org/10.1080/09668136.2018.1520525

MAURIZIO G. TOTARO (C) 2018

Ivor Roberts, Conversations with Milošević. Athens, GA: University of Georgia Press, 2016, xxxiii +177 pp., $\$ 32.95 \mathrm{~h} / \mathrm{b}$.

IN CONVERSATIONS WITH MILOŠEVIĆ, IVOR ROBERTS RECOUNTS HIS EXPERIENCE between 1994 and 1997 as UK ambassador to the Federal Republic of Yugoslavia (FRY), the rump state established after the dissolution of the Socialist Federal Republic of Yugoslavia (SFRY) in 1992, and which at the time consisted of Serbia, Montenegro and the autonomous provinces of Kosovo and Vojvodina. In the Introduction, Roberts investigates in detail the reasons behind the SFRY's violent disintegration, arguing that 